\title{
Prevotella bryantii 25A Used as a Probiotic in Early-Lactation Dairy Cows: Effect on Ruminal Fermentation Characteristics, Milk Production, and Milk Composition ${ }^{1}$
}

\author{
J. Chiquette, ${ }^{* 2}$ M. J. Allison, $†$ and M. A. Rasmussen $\ddagger$ \\ *Dairy and Swine Research and Development Centre, 2000 College, Sherbrooke, Québec, Canada, J1M 1 Z3 \\ †lowa State University, 313 Kildee Hall, Ames 50011-3211 \\ $\ddagger$ National Animal Disease Center-ARS-USDA, 2300 Dayton Ave., Ames, IA 50010
}

\begin{abstract}
Ingestion of high levels of rapidly fermented carbohydrates after parturition often leads to the production of excessive quantities of organic acids that may exceed the buffering capacity of the rumen and cause $\mathrm{pH}$ to drop. Ruminal acidosis results in animal discomfort, anorexia, depression, decreased digestibility, and decreased milk production. In the present study, we examined the effects of daily addition of cells of a newly isolated strain of Prevotella bryantii (25A) to the rumen of 12 ruminally cannulated cows in early lactation. This strain was selected based on earlier in vitro studies that indicated its ability to grow rapidly, compete for starch, and produce organic acids other than lactate. After calving, all cows received increasing amounts of an energy-dense diet containing barley grain, corn silage, and grass silage in a 40:60 forageto-concentrate ratio. Animals were blocked according to milk production from their previous lactation. Treatments (control and $P$. bryantii) were distributed among cows within the same block. Cows were fed once a day. Six cows were given a daily dose of $P$. bryantii (2 $\times 10^{11}$ cells/dose), administered directly with a syringe through the rumen cannula, from 3 wk prepartum up to 7 wk postpartum. Rumen fluid was sampled before feeding and at 2 and $3 \mathrm{~h}$ postfeeding on wk 1, 2, 3, 4, 6 , and 7 postpartum. Feed intake and milk yield were recorded daily and milk composition was recorded $2 \mathrm{~d} /$ wk, up to wk 7 of lactation. Feed intake was similar between control and treated cows. Prevotella bryantii did not change milk production, but milk fat tended to be greater in treated cows compared with control cows (3.9 vs. $3.5 \%$ ). Rumen $\mathrm{pH}$ was similar between the 2 groups and differed across sampling times, being higher before feeding (6.3) as opposed to $2 \mathrm{~h}$ (5.9)

\footnotetext{
Received November 9, 2007.

Accepted May 9, 2008.

${ }^{1}$ Contribution number 961 from Agriculture and Agri-Food

${ }^{2}$ Corresponding author: chiquettej@agr.gc.ca
} Canada, Sherbrooke, Québec, Canada.
\end{abstract}

and $3 \mathrm{~h}$ (5.7) postfeeding. Rumen lactate concentration was similar before feeding between control and treated cows; however, 2 to $3 \mathrm{~h}$ after feeding, lactate concentration was lower in cows receiving $P$. bryantii compared with control cows ( 0.7 vs. $1.4 \mathrm{mM})$. This difference was maintained throughout the experimental period. Concentration of $\mathrm{NH}_{3}-\mathrm{N}$ was greater in treated cows than in control cows (174 vs. $142 \mathrm{mg} / \mathrm{L}$ ). Acetate (65.5 vs. $57.8 \mathrm{mM}$ ), butyrate (12.7 vs. $10.5 \mathrm{mM}$ ), and branchedchain $\mathrm{C} 4$ fatty acid (0.90 vs. $0.75 \mathrm{mM}$ ) concentrations were greater in postfeeding samples of treated cows compared with control cows. Supplementing earlylactating cows with $P$. bryantii $25 \mathrm{~A}$ increased ruminal fermentation products and milk fat concentration. Because signs of subacute ruminal acidosis were not observed in either treated or control cows, no conclusions can be made about possible protection against acidosis by $P$. bryantii.

Key words: Prevotella bryantii 25A, transition dairy cow, probiotic, rumen modification

\section{INTRODUCTION}

The period after parturition, when a change in diet occurs to meet the energy required for milk production, is most critical for the health of dairy cows. Large quantities of rapidly fermentable carbohydrates are often fed to meet the increased demand for energy, and this may lead to production of organic acids (VFA and lactate) in amounts that exceed the buffering capacity of the rumen. Problems may also arise from the lack of an adequate adaptation period, during which the epithelium papillae develop and provide increased absorption of VFA (Krause and Oetzel, 2006).

If $\mathrm{pH}$ drops below 6.0, fiber digestibility is impaired (Stewart, 1977). When $\mathrm{pH}$ values drop between 5.2 and 5.6, animals may show clinical signs of subacute ruminal acidosis (SARA), causing animal discomfort and decreased production performance (Duffield et al., 2004).

Several dietary strategies for this critical period were reported in the review by Krause and Oetzel (2006), 
including feeding unprocessed grains that are less fermentable; providing TMR instead of separate ingredients; feeding smaller meals more frequently and at regular intervals; and introducing grains progressively so that the rumen microbial population can adapt. It is also recommended that ration formulations provide a minimum content of total and physically effective fiber. However, this is not always sufficient, because cows are able to sort out long feed particles (Bach, 2007).

In spite of these precautions, some animals are more susceptible to a $\mathrm{pH}$ drop, and additional measures to prevent SARA could prove beneficial. Several studies investigated the role of monensin (an antibioticionophore) in preventing SARA, and although some reported elevation of rumen $\mathrm{pH}$ by reducing concentrations of VFA with no effect on rumen lactate (Burrin and Britton, 1986), others reported no effect on rumen pH (Mutsvangwa et al., 2002; Osborne et al., 2004). However, because of general concerns about antibiotics, recent research has evaluated the use of live microorganisms with the aim of maintaining greater ruminal $\mathrm{pH}$ when feeding early-lactation dairy cows (Nocek et al., 2002; Beauchemin et al., 2003).

In the present study, we used a new strain of Prevotella bryantii that was selected and isolated based on its ability to grow rapidly on starch media and to produce end products other than lactate (mainly succinate and propionate; Rodriguez, 2003). In a preliminary study in which $P$. bryantii $25 \mathrm{~A}$ was introduced in the rumen of 3 goats submitted to a lactic acidosis challenge, Rodriguez (2003) observed that ruminal $\mathrm{pH}$ was lower in control animals after an acidosis challenge. Rumen lactate concentration peaked at $80 \mathrm{~m} M$ after 8 $\mathrm{h}$ and remained elevated in control animals, whereas a maximal lactate concentration of $15 \mathrm{~m} M$ was recorded in treated animals during the 4 to $8 \mathrm{~h}$ of starch exposure. A rapid decline to less than $3 \mathrm{~m} M$ was also observed in treated animals after $12 \mathrm{~h}$. The hypothesis of the present study was that dosing the rumen with $P$. bryantii $25 \mathrm{~A}$ would modulate rumen fermentation and reduce transient spikes of rumen lactate, with a resulting increase in rumen $\mathrm{pH}$ and animal performance, during early lactation.

\section{MATERIALS AND METHODS}

\section{Animals, Feeding, and Sampling Procedure}

Twelve multiparous rumen-fistulated dairy cows were used. All cows were fed a high-forage diet consisting of grass hay with mineral and vitamin supplements, from wk -6 to -3 relative to parturition (Table 1). Three weeks before calving, cows received the diet shown in Table 1. After calving, all cows received in- creasing amounts of an energy-dense diet containing barley grain, corn silage, and grass silage in a 40:60 forage-to-concentrate ratio (Table 1). Animals were blocked according to milk production from their previous lactation. Treatments (control and $P$. bryantii) were distributed between cows within the same block. Milk production from the previous lactation was, on average, 9,333 and 9,349 $\mathrm{kg}$ for cows identified as control or receiving $P$. bryantii, respectively. All cows received an additional $1.5 \mathrm{~kg} / \mathrm{d}$ of hay during the first week after parturition. They were fed once a day at $0900 \mathrm{~h}$ throughout the experimental period to increase the variation in postfeeding ruminal $\mathrm{pH}$ (Krause and Oetzel, 2006). Six cows were given $P$. bryantii once a day before feeding via the rumen cannula, from $3 \mathrm{wk}$ prepartum to $7 \mathrm{wk}$ postpartum. Rumen fluid was sampled before feeding, 2 and $3 \mathrm{~h}$ postfeeding (2- and 3-h samples were pooled before analysis) on wk 1, 2, 3, 4, 6 , and 7 postpartum. Feed intake and milk yield were recorded daily up to wk 7 of lactation. Milk samples were taken on 4 consecutive milkings each week for analysis of milk composition. Rumen fluid samples were analyzed for $\mathrm{pH}$ (immediately after collection), VFA, $\mathrm{NH}_{3}-\mathrm{N}$, and lactate. All animals were cared for according to standards set by the Canadian Council on Animal Care (1993).

\section{Preparation of the Probiotic Strain}

Cells of Prevotella bryantii, strain 25A, that had been isolated and described by Rodriguez (2003) were grown under a $\mathrm{CO}_{2}$ atmosphere in an anaerobic medium containing mineral salts, cysteine: $\mathrm{HCl}$, yeast extract, and a mixture of VFA, with wheat starch as substrate. Cells were grown to the late-log phase in a 100-L fermenter and were harvested by centrifugation following a 15 -fold concentration by using a hollow fiber system (Amicon DC 10L, Amicon, Beverly, MA). The cell paste was suspended in approximately $2.5 \mathrm{~L}$ of spent medium containing $10 \%$ dimethylsulfoxide and was dispensed in individual doses in plastic syringes $(25 \mathrm{~mL})$, which were frozen and maintained at $-86^{\circ} \mathrm{C}$ until used. Precautions were taken to limit exposure of the harvested cells to air until frozen. Before inoculation of cows, viable cell concentrations of these preparations were determined by serial dilution and plate count on agar medium in an anaerobic chamber (Bactron 1, Sheldon Manufacturing Inc., Cornelius, OR). Counts ranged from 2 to $29 \times 10^{10} \mathrm{cfu} /$ dose.

\section{DMI, Milk Yield, and Composition}

Feed intake was recorded daily from parturition to wk 7 of lactation. Weighed TMR, allowing approxi- 
Table 1. Composition of the rations (DM basis) served to dry and lactating cows

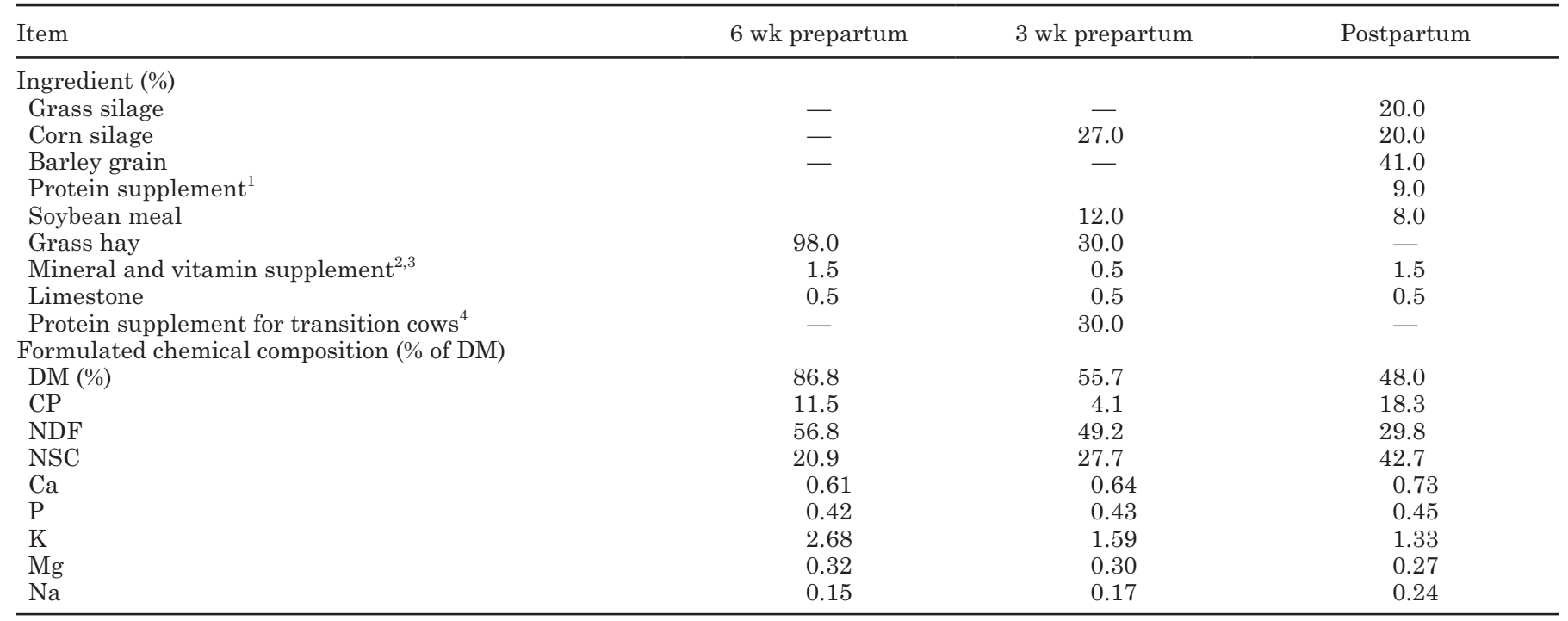

${ }^{1}$ Protein supplement contained the following: corn distillers grain (25\%), wheat distillers grain (15\%), canola meal (15\%), SoyPLUS (45\%; Omnigrains, St-Germain de Grantham, Québec, Canada).

${ }^{2}$ Vitamin-mineral mix (prepartum) contained the following: major minerals (\%): Ca (3.0), P (12.0), Mg (12.0), Na (2.4), K (1.4), S (2.3); minor minerals (mg/kg): Fe (4,860), Mn (6,580), Zn (7,720), Cu (1,670), F (1,200), I (205), Co (122), Se (40); vitamins (IU/kg): vitamin A (811,200), vitamin D $(245,000)$, vitamin $\mathrm{E}(7,600)$.

${ }^{3}$ Vitamin-mineral mix (postpartum) contained the following: major minerals (\%): Ca (9.5), P (5.5), $\mathrm{Mg}$ (5.5), $\mathrm{Na}(13.0), \mathrm{Cl}(15.0), \mathrm{K}(1.4), \mathrm{S}$ (2.1); minor minerals (mg/kg): Fe (2,745), Mn (2,065), Zn (3,000), Cu (495), I (69), Co (33), Se (20); vitamins (IU/kg): vitamin A (501,859), vitamin $\mathrm{D}(65,000)$, vitamin $\mathrm{E}(2,600)$.

${ }^{4}$ The following ingredients constituted $80 \%$ of the supplement: canola meal, sugarbeet pulp, soyhulls, cornmeal, wheat, gluten feed, gluten meal, wheat distillers grain, wheat middlings. A mineral-vitamin premix constituted the remaining $20 \%$ (Coop Fédérée, Montreal, Québec, Canada).

mately $10 \%$ refusals, was distributed to each cow with a feed cart with load cells (Rovibec, model 530, Coaticook, Québec, Canada). After 24 h, feed refusals were weighed for each cow. The TMR was sampled once a week and hay was sampled on wk 1 for DM analysis by near-infrared spectroscopy (Foss NIR Systems Inc., Laurel, MD). Milk yield was also recorded daily from parturition to wk 7 of lactation by using Metatron units with $2 \%$ accuracy (Westfalia Surge, Victoriaville, Québec, Canada) in a herringbone-type milking parlor. Milk samples were taken on 4 consecutive milkings (Monday evening, Tuesday morning, Tuesday evening, and Wednesday morning) during each week from parturition to wk 7 of lactation. Milk samples were kept at $4^{\circ} \mathrm{C}$, using bronopol as a preservative, and were shipped weekly to Valacta (the DHI organization responsible for milk recording in the province of Québec). The content of milk fat, protein, and urea $\mathrm{N}$ was determined by using a near-infrared analyzer (Foss Electric, Hillerød, Denmark) according to AOAC (1990).

\section{Rumen Sampling and $\mathrm{pH}$ Measurement}

Rumen content was sampled on wk 1, 2, 3, 4, 6, and 7 of lactation. On each of those weeks, samples were taken before feeding and at 2 and $3 \mathrm{~h}$ postfeeding. Handfuls of rumen content (solid and liquid) were sampled through the rumen cannula from the ventral, posterior, and anterior sacs of the rumen. The content was squeezed to remove liquid from the solid (approximately $750 \mathrm{~mL}$ ), and some solid particles were added to a 1-L container. The content was mixed and subsampled for bacterial DNA quantification (unpublished data). The remaining content was strained through 4 layers of cheesecloth to remove large particles. Rumen $\mathrm{pH}$ was measured within 15 min of collection by using an Oakton $1000 \mathrm{pH}$ meter (Fisher Scientific, Nepean, Ontario, Canada). Samples for $\mathrm{NH}_{3}-\mathrm{N}$ and lactate were kept at $-20^{\circ} \mathrm{C}$. Samples for VFA were acidified [ $5 \mathrm{~mL}$ of filtered rumen fluid and $1 \mathrm{~mL}$ of $\mathrm{H}_{2} \mathrm{SO}_{4}(0.5 \mathrm{M})$ ] before freezing at $-20^{\circ} \mathrm{C}$. Postfeeding samples were pooled by cow and by day before analysis.

\section{VFA and Lactate Determination}

Upon thawing, VFA samples were centrifuged $(29,000$ $\times \mathrm{g}, 20 \mathrm{~min}, 4^{\circ} \mathrm{C}$ ). Approximately $1 \mathrm{~mL}$ of resin (Dowex 50 WX8-100, Sigma-Aldrich, St. Louis, MO) was added and incubated for $10 \mathrm{~min}$, and samples were filtered through a $0.22-\mu \mathrm{m}$ syringe filter. Subsamples $(0.5 \mu \mathrm{L})$ 
Table 2. Effect of Prevotella bryantii $25 \mathrm{~A}$ and sampling time on concentrations of VFA (mM), lactate $(\mathrm{m} M), \mathrm{NH}_{3}-\mathrm{N}$ (mg/L), and $\mathrm{pH}$ before feeding and at 2 and $3 \mathrm{~h}$ after feeding

\begin{tabular}{|c|c|c|c|c|c|c|c|c|}
\hline \multirow[b]{2}{*}{ Item } & \multicolumn{4}{|c|}{ Prefeeding } & \multicolumn{4}{|c|}{ Postfeeding } \\
\hline & Control & P. bryantii & SEM & $P$-value & Control & P. bryantii & SEM & $P$-value \\
\hline Propionate (P) & 20.8 & 19.0 & 1.15 & 0.27 & 26.3 & 26.3 & 1.38 & 0.99 \\
\hline Butyrate & 6.59 & 8.24 & 0.50 & 0.03 & 10.5 & 12.7 & 0.53 & 0.01 \\
\hline Valerate & 0.90 & 0.94 & 0.07 & 0.71 & 1.42 & 1.51 & 0.18 & 0.72 \\
\hline $\mathrm{A}: \mathrm{P}$ & 2.51 & 2.93 & 0.14 & 0.05 & 2.31 & 2.60 & 0.12 & 0.10 \\
\hline Lactate $^{3}$ & 0.21 & 0.21 & - & 0.56 & 1.40 & 0.70 & - & 0.05 \\
\hline $\mathrm{NH}_{3}-\mathrm{N}$ & 132 & 156 & 11.7 & 0.17 & 152 & 195 & 13.9 & 0.03 \\
\hline $\mathrm{pH}$ & 6.33 & 6.24 & 0.05 & 0.17 & 5.84 & 5.79 & 0.04 & 0.39 \\
\hline
\end{tabular}

${ }^{1}$ Branched-chain $\mathrm{C} 4$ acids.

${ }^{2}$ Branched-chain $\mathrm{C} 5$ acids.

${ }^{3}$ Because there was a lack of normality in the distribution of lactate values, they were analyzed with a generalized linear mixed model by using the gamma distribution and the logarithmic link function of the GLIMMIX procedure, which best fit the lactate data distribution. Standard errors cannot be generated with this model; therefore, minimum and maximum values associated with each mean are presented for control prefeeding $(0.13,0.45), P$. bryantii prefeeding $(0.14,1.43)$, control postfeeding $(0.21,7.35)$, and $P$. bryantii postfeeding $(0.18,3.24)$.

were analyzed by using a Hewlett-Packard model 6890 gas chromatograph (Agilent Technology Canada Inc., Mississauga, Ontario, Canada). The column used was a Stabilwax-DA $(30 \mathrm{~m} \times 0.53 \mathrm{~mm} \times 0.50 \mu \mathrm{m}$; Chromatographic Specialties, Brockville, Ontario, Canada). Temperatures of the injector and detector were 250 and $300^{\circ} \mathrm{C}$, respectively. Filtered rumen fluid $(5 \mathrm{~mL})$ was added in duplicate vials and analyzed for lactate by using the colorimetric assay of Taylor (1996).

\section{NH3-N}

Filtered rumen content was centrifuged $(17,750 \times g$, for 5 min at $4^{\circ} \mathrm{C}$ ) and the supernatant was analyzed by using the phenol-hypochlorite reaction (Weatherburn, 1967) with volumes adapted for microplates.

\section{Statistical Analysis}

Variables were analyzed as a randomized complete block design, with blocks as a random factor and $P$. bryantii versus the control as a fixed factor. Repeated measurements in time (week) were added to the model when appropriate, and the analysis was performed with the MIXED procedure of SAS (release 9.1, 2002, SAS Institute Inc., Cary, NC).

The model for VFA and $\mathrm{NH}_{3}-\mathrm{N}$ was that of double repeated measures, with hours and week as the 2 repeated measures. Because there was a lack of normality in their distribution, lactate values were analyzed with a generalized linear mixed model by using the gamma distribution and the logarithmic link function of the GLIMMIX procedure, which best fit the lactate data distribution. Standard errors cannot be generated with this model; therefore, minimum and maximum values associated with each mean are presented in Table 2 for lactate.

\section{RESULTS AND DISCUSSION}

\section{VFA}

Total VFA concentration was greater $(P=0.0001)$ in postfeeding than in prefeeding samples (103.4 and $81.1 \mathrm{~m} M$ for post- and prefeeding, respectively; Table 2). Cows receiving $P$. bryantii tended to have a greater concentration of total VFA postfeeding $(P=0.07)$. There was no effect of weeks after parturition on total VFA. Similarly, there was more of each individual VFA postfeeding than prefeeding (Table 2). Before feeding, acetate concentration tended to be greater in treated cows compared with control cows $(P=0.10)$, but it was greater in treated cows postfeeding $(P=0.004)$ throughout the experimental weeks. Butyrate concentration was greater with the $P$. bryantii $25 \mathrm{~A}$ treatment compared with the control treatment in both the prefeeding $(P=0.03)$ and postfeeding $(P=0.01)$ samples. Propionate concentration was similar between the treated and control groups at both sampling times (19.9 and $26.3 \mathrm{mM}$, for pre- and postfeeding concentrations, respectively). Prevotella bryantii $25 \mathrm{~A}$ was shown to produce succinate as a result of starch fermentation in vitro, and given that succinate is rapidly metabolized to propionate in the rumen (Blackburn and Hungate, 1963), we would have expected a greater propionate concentration associated with treated cows. Rumen succinate concentration was not measured in the present study. 
The concentrations of branched-chain $\mathrm{C} 4$ and branched-chain $\mathrm{C} 5$ acids were similar in control and treated cows before feeding. Postfeeding, however, the branched-chain $\mathrm{C} 4$ acid concentration was greater in treated animals compared with the control group $(P=$ 0.02) and the branched-chain C5 concentration tended to be greater in treated than in control cows $(P=0.08)$. This increased concentration of branched-chain VFA in the presence of $P$. bryantii suggests an increased rate of proteolysis and AA metabolism in animals receiving $P$. bryantii 25A. The increased concentrations of acetate and butyrate would suggest an increased rate of fiber fermentation. Moreover, $P$. bryantii 25A could itself have cellulolytic activity, because Rodriguez (2003) reported that $P$. bryantii $25 \mathrm{~A}$ could ferment xylan in vitro. More recently, Sawanon and Kobayashi (2006) reported synergistic fibrolysis in the rumen by cellulolytic Ruminococcus and noncellulolytic Selenomonas ruminantium. Synergistic fibrolysis by $P$. bryantii and cellulolytic bacteria cannot be ruled out, given the fermentation characteristics observed in the present study. The possible increase in cellulolytic activity when dosing the rumen with $P$. bryantii $25 \mathrm{~A}$ will need further investigation.

Before feeding, the acetate-to-propionate ratio was greater in treated animals compared with control animals $(P=0.05)$ and it tended to be greater in postfeeding samples $(P=0.10)$. Important fluctuations in the ratio were recorded in control animals during the first 2 wk after parturition, although the ratio was more stable in treated cows. These results differ from those obtained by Rodriguez (2003) with goats (3 animals per treatment) subjected to a lactic acidosis challenge and inoculated with freshly grown, nonpreserved $P$. bryantii cultures. In their study, goats receiving $P$. bryantii had greater concentrations of ruminal acetate, butyrate, propionate, and valerate compared with control goats. They observed no difference in ruminal isoacid concentrations. Several key differences between these studies (animal species, challenging the animal for acidosis, freshly grown as opposed to preserved $P$. bryantii cultures) may explain the contrasting results.

\section{Lactate}

Lactate concentration in rumen fluid before feeding did not differ between the 2 groups of cows and was $0.21 \mathrm{~m} M$ (Table 2). Cows receiving P. bryantii 25A had lower postfeeding ruminal lactate concentrations $(P=0.05)$ throughout the experimental period, averaging $0.7 \mathrm{~m} M$ compared with $1.4 \mathrm{~m} M$ in the control cows, with concentrations ranging from 0.2 to $7.4 \mathrm{mM}$ in the control group and 0.2 to $3.2 \mathrm{mM}$ in the treated group. These results are in accordance with what was previously observed in vitro and with goats receiving P. bryantii 25A (Rodriguez, 2003), although the difference between control and treated animals was less pronounced in the present study. Both studies reflect the ability of the strain to ferment starch and to compete with lactic acid-producing bacteria for this substrate. Lactate concentrations observed in the present study were within what is considered normal $(<5 \mathrm{mM}$; Oetzel et al., 1999), with the exception of 3 postfeeding samples at 5.5, 5.8, and 7.4 $\mathrm{mM}$. Krause and Oetzel (2005) reported a lactate concentration peak of $16 \mathrm{mM}$ during SARA.

\section{Ruminal $\mathrm{pH}$}

As expected, rumen $\mathrm{pH}$ was lower in the 2- and 3-h postfeeding samples compared with the prefeeding samples in control and treated cows $(P=0.0001)$, but there was no effect of treatment on rumen $\mathrm{pH}$ (Table 2). It is possible that the increased concentration of VFA observed in treated animals relative to the control (11 $\mathrm{m} M$ ) was partly cancelled out by the decreased lactate concentration in those same animals $(0.7 \mathrm{mM})$. Considering that lactic acid is approximately 10 times stronger than VFA (pKa 3.9 vs. 4.9; Nagaraja and Titgemeyer, 2007), the decrease in lactic acid would correspond to a $7 \mathrm{~m} M$ decrease in VFA, which still results in a net positive increase in VFA $(4 \mathrm{mM})$ in treated animals. This could explain the lower ruminal $\mathrm{pH}$ that was systematically observed in treated animals compared with the control, although this was not significant (Figure 1). In the present study, $\mathrm{pH}$ remained above 5.5, which is greater than what is generally considered as the SARA zone $(5.2<\mathrm{pH}<5.6$; Owens et al., 1998; Keunen et al., 2002; Nagaraja and Titgemeyer, 2007). Average $\mathrm{pH}$ was 6.0 and 5.9 for control and treated cows, respectively. Cows did not show any signs of SARA, such as intermittent feed intake or decreased milk production. Usually SARA is more likely to occur in high-producing dairy cows (Osborne et al., 2004). Krause and Oetzel (2006) reported that primiparous cows are more at risk for SARA than are multiparous cows. Cows in the present study were multiparous and produced an average of $35 \mathrm{~kg}$ of milk daily.

Undoubtedly, continuous $\mathrm{pH}$ measurement would have allowed a better evaluation of the duration and severity of $\mathrm{pH}$ drop after feeding. Continuous $\mathrm{pH}$ measurements are reported in the literature, although usually with a smaller number of animals (4 to 9; Keunen et al., 2002; Mutsvangwa et al., 2002; Nocek et al., 2002).

\section{Ruminal $\mathrm{NH}_{3}-\mathrm{N}$}

Rumen $\mathrm{NH}_{3}-\mathrm{N}$ concentration increased with weeks postpartum in the control and treated animals $(P=$ 


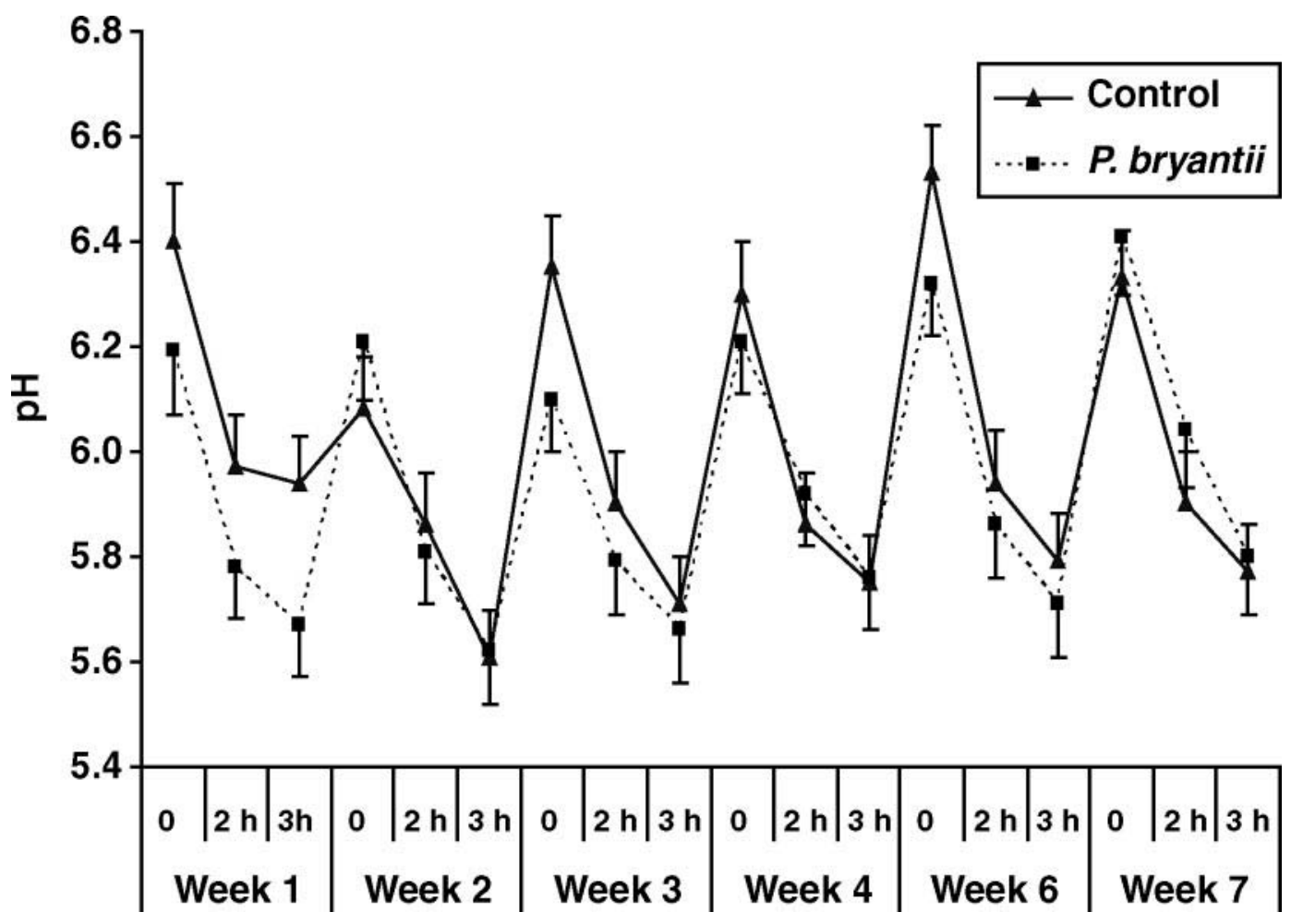

Figure 1. Effect of Prevotella bryantii 25A on ruminal $\mathrm{pH}$ at 0,2 , and $3 \mathrm{~h}$ after feeding for $7 \mathrm{wk}$ after parturition (bars represent SD).

0.0003) as the level of feed intake increased. Concentration of $\mathrm{NH}_{3}-\mathrm{N}$ was greater in postfeeding samples (173.5 mg/L) compared with prefeeding samples (141.8 $\mathrm{mg} / \mathrm{L} ; P=0.001)$ throughout the experimental period. Treated cows had a greater rumen $\mathrm{NH}_{3}-\mathrm{N}$ concentration than that recorded in the control cows postfeeding (195.4 and $152.2 \mathrm{mg} / \mathrm{L}$ for treated and control cows, respectively $(P=0.03$; Table 2$)$. We do not have a definitive explanation for this, although it could be indicative of a greater proteolytic and deamination activity by $P$. bryantii, which is generally thought to make a significant contribution to the degradation of starch, proteins, and peptides in the rumen (Stewart et al., 1997). It is also in accordance with the greater concentrations of iso-acids observed in treated cows. These iso-acids are produced by bacteria that deaminate and decarboxylate branched-chain AA (Allison et al., 1962).

These $\mathrm{NH}_{3}-\mathrm{N}$ concentrations are within the limits of what is generally reported in the literature (Einarson et al., 2005; Benchaar et al., 2006; Raeth-Knight et al., 2007) but are beyond the concentration of $50 \mathrm{mg} / \mathrm{L}$ generally recognized as the minimum concentration for microbial protein synthesis (Satter and Roffler 1974). For other authors, the optimum $\mathrm{NH}_{3}-\mathrm{N}$ concentration would be in the range of 85 to $162 \mathrm{mg} / \mathrm{L}$ (Ørskov et al.,
1972; Kang-Meznarich and Broderick 1980; Pisulewski et al., 1981).

\section{DMI, Milk Production, and Composition}

Dry matter intake increased linearly from wk 1 to 5 of parturition $(P=0.0001)$ and was, on average, 14.6 $\mathrm{kg} / \mathrm{d}$ on wk 1 and $23.5 \mathrm{~kg} / \mathrm{d}$ on wk 5 after parturition, after which it stabilized, resulting in a quadratic effect $(P=0.0001$; Table 3$)$. Dry matter intake was not different between animals in the $P$. bryantii and control groups (21.2 kg of DM/d; $P=0.49$ ).

Milk production $(35.1 \mathrm{~kg} / \mathrm{d})$ and FCM $(33.4 \mathrm{~kg} / \mathrm{d}$ ) were not different between treatments. These results for DMI and milk production should be interpreted with caution because of the relatively small number of animals used for production data. Milk production increased linearly $(P=0.0001)$ from wk $1(26.5 \mathrm{~kg} / \mathrm{d})$ to wk $5(37.9 \mathrm{~kg} / \mathrm{d})$ of lactation. Quadratic and cubic effects were observed with weeks of milk production (Table 3). A similar evolution in DMI and milk production during lactation was reported by Pollott (2004).

There was a tendency for greater milk fat content in cows receiving $P$. bryantii (3.87\%) as compared with control cows $(3.54 \% ; P=0.06)$ throughout the lacta- 


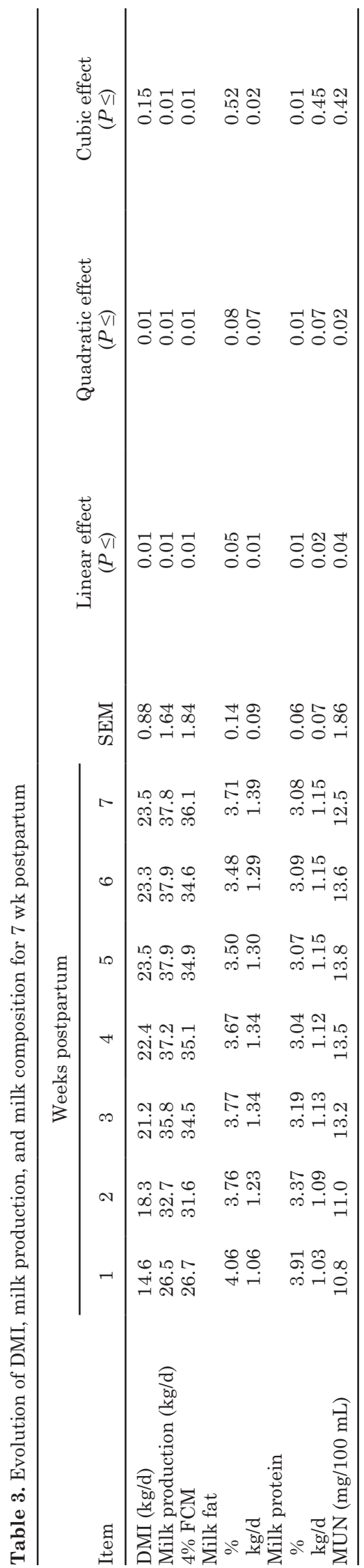

tion weeks. This would be in accordance with greater acetate and butyrate concentrations in the rumen of treated cows, because those VFA are precursors for milk fat synthesis. Milk fat yield, milk protein content, milk protein yield, and MUN concentrations were not affected by treatment and averaged $1.3 \mathrm{~kg} / \mathrm{d}, 3.25 \%, 1.1$ $\mathrm{kg} / \mathrm{d}$, and $12.6 \mathrm{mg} / 100 \mathrm{~mL}$, respectively. There was no interaction between treatment and lactation weeks for milk components. Milk fat percentage showed a much slower decrease than milk protein percentage throughout the lactation weeks, with the minimum milk fat percentage observed at wk 6 , as compared with wk 4 for the minimum milk protein percentage (Table 3). Very similar observations in the evolution of milk fat and protein content throughout lactation were reported by Martin and Sauvant (2007). Conversely, milk fat yield showed a faster increase in early lactation compared with milk protein yield, with a peak at wk $3(1.34 \mathrm{~kg} / \mathrm{d})$ compared with wk 5 for the peak of protein yield (1.15 $\mathrm{kg} / \mathrm{d}$; Table 3). Pollott (2004) reported similar behavior in time for milk fat and protein yields in early lactation, with the exception that their model predicted that fat yield would peak in wk $5(1.20 \mathrm{~kg} / \mathrm{d})$ and protein yield would peak in wk $8(1.05 \mathrm{~kg} / \mathrm{d})$.

Similar to DMI and milk production, MUN concentration increased up to wk 5 of lactation and decreased slowly thereafter. A concomitant peak in MUN and milk production was observed by Rajala-Schultz and Saville (2003). They associated the lower concentration of MUN at the beginning of lactation with the difficulty of high-producing cows to ingest a sufficient amount of feed to meet their requirements for energy, resulting in suboptimal functioning of the ruminal flora. Wattiaux and Karg (2004) reported an average of $12.5 \mathrm{mg} / 100$ $\mathrm{mL}$ of MUN with their high-protein diet (17.5\%) as compared with $11.6 \mathrm{mg} / 100 \mathrm{~mL}$ with their low-protein diet (16.4\%). In the present study, the average MUN was $12.6 \mathrm{mg} / 100 \mathrm{~mL}$ and the postpartum diet was formulated to provide $18.3 \% \mathrm{CP}$.

\section{CONCLUSIONS}

Dosing the rumen with $P$. bryantii $25 \mathrm{~A}$ increased the concentration of fermentation products in the rumen, indicating that feed digestion might be increased. Milk fat tended to increase in animals receiving $P$. bryantii $25 \mathrm{~A}$, which is in accordance with increased acetate and butyrate concentrations in the rumen of treated cows. The increased iso-acid concentration in treated cows is indicative of increased proteolytic and deamination activity in the presence of $P$. bryantii 25A. Prevotella bryantii also decreased lactate concentration after feeding compared with the control treatment. Both of these effects (reduction in lactate concentration and increase 
in $\mathrm{NH}_{3}-\mathrm{N}$ concentration) would contribute toward prevention of rumen acidosis in early-lactating cows.

\section{ACKNOWLEDGMENTS}

The authors thank Dairy Farmers of Canada (Ottawa, Ontario, Canada) and Agriculture and Agri-Food Canada (Sherbrooke, Québec, Canada) for financial support of this research. The technical assistance of $\mathrm{F}$. Markwell, A. Payet-Maugeron, H. Cook, and S. Franklin is greatly acknowledged. Appreciation is expressed to S. Méthot for statistical analysis and C. Bolduc and D. Thibault for care of the experimental cows.

\section{REFERENCES}

Allison, M. J., M. P. Bryant, and R. N. Doetsch. 1962. Studies on the metabolic function of branched-chain volatile fatty acids, growth factors for ruminococci. 1. Incorporation of isovalerate into leucine. J. Bacteriol. 83:523-532.

AOAC. 1990. Official Methods of Analysis. 15th ed. Assoc. Off. Anal. Chem., Arlington, VA.

Bach, A. 2007. The importance of ruminal $\mathrm{pH}$ and the impact of probiotics on reducing the incidence of subacute acidosis. Pages 7-20 in Proc. of the 43rd Eastern Nutrition Conference, Québec, Canada. Anim. Nutr. Assoc. Canada, Ottawa, Ontario, Canada.

Beauchemin, K. A., W. Z. Yang, D. P. Morgavi, G. R. Ghorbani, W. Kautz, and J. A. Z. Leedle. 2003. Effects of bacterial directfed microbials and yeast on site and extent of digestion, blood chemistry, and subclinical ruminal acidosis in feedlot cattle. J. Anim. Sci. 81:1628-1640.

Benchaar, C., H. V. Petit, R. Berthiaume, T. D. Whyte, and P. Y. Chouinard. 2006. Effects of addition of essential oils and monensin premix on digestion, ruminal fermentation, milk production, and milk composition in dairy cows. J. Dairy Sci. 89:4352-4364.

Blackburn, T. H., and R. E. Hungate. 1963. Succinic acid turnover and propionate production in the rumen. Appl. Microbiol. $11: 132-135$

Burrin, D. G., and R. A. Britton. 1986. Response to monensin in cattle during subacute acidosis. J. Anim. Sci. 63:888-893.

Canadian Council on Animal Care. 1993. Guide to the Care and Use of Experimental Animals. 2nd ed. Vol. 1. E. D. Olfert, B. M. Cross, and A. A. McWilliams, ed. Can. Counc. Anim. Care, Ottawa, Ontario, Canada.

Duffield, T., J. C. Plaizier, A. Fairfield, R. Bagg, G. Vessie, P. Dick, J. Wilson, J. Aramini, and B. W. McBride. 2004. Comparison of techniques for measurement of rumen $\mathrm{pH}$ in lactating dairy cows. J. Dairy Sci. 87:59-66.

Einarson, M. S., J. C. Plaizier, and K. M. Wittenberg. 2005. Effects of including chopped alfalfa hay in barley-based total mixed rations on production and rumen fermentation in dairy cows. Can. J. Anim. Sci. 85:251-253.

Kang-Meznarich, J. H., and G. A. Broderick. 1980. Effects of incremental urea supplementation on ruminal ammonia concentration and bacterial protein fermentation. J. Anim. Sci. 51:422-431.

Keunen, J. E., J. C. Plaizier, L. Kyriazakis, T. F. Duffield, T. M. Widowski, M. I. Lindinger, and B. W. McBride. 2002. Effects of a subacute ruminal acidosis model on the diet selection of dairy cows. J. Dairy Sci. 85:3304-3313.

Krause, K. M., and G. R. Oetzel. 2005. Inducing subacute ruminal acidosis in lactating dairy cows. J. Dairy Sci. 88:3633-3639.
Krause, K. M., and G. R. Oetzel. 2006. Understanding and preventing subacute ruminal acidosis in dairy herds: A review. Anim. Feed Sci. Technol. 126:215-236.

Martin, O., and D. Sauvant. 2007. Dynamic model of the lactating dairy cow metabolism. Animal 1:1143-1166.

Mutsvangwa, T., J. D. Walton, J. C. Plaizier, T. F. Duffield, R. Bagg, P. Dick, G. Vessie, and B. W. McBride. 2002. Effects of a monensin controlled-release capsule or premix on attenuation of subacute ruminal acidosis in dairy cows. J. Dairy Sci. 85:3454-3461.

Nagaraja, T. G., and E. C. Titgemeyer. 2007. Ruminal acidosis in beef cattle: The current microbiological and nutritional outlook. J. Dairy Sci. 90(E Suppl.):E17-E38.

Nocek, J. E., W. P. Kautz, J. A. Z. Leedle, and J. G. Allman. 2002. Ruminal supplementation of direct-fed microbials on diurnal $\mathrm{pH}$ variation and in situ digestion in dairy cattle. J. Dairy Sci. 85:429-433.

Oetzel, G. R., K. V. Nordlund, and E. F. Garrett. 1999. Effect of ruminal $\mathrm{pH}$ and stage of lactation on ruminal lactate concentrations in dairy cows. J. Dairy Sci. 82(Suppl. 1):38. (Abstr.)

Ørskov, E. R., C. Fraser, and I. McDonald. 1972. Digestion of concentrates in sheep. 4 . The effects of urea on digestion, nitrogen retention and growth in young lambs. Br. J. Nutr. 27:491-501.

Osborne, J. K., T. Mutsvangwa, O. Alzahal, T. F. Duffield, R. Bagg, P. Dick, G. Vessie, and B. W. McBride. 2004. Effects of monensin on ruminal forage digestibility and total tract diet digestibility in lactating dairy cows during grain-induced subacute ruminal acidosis. J. Dairy Sci. 87:1840-1847.

Owens, F. N., D. S. Secrist, W. J. Hill, and D. R. Gill. 1998. Acidosis in cattle: A review. J. Anim. Sci. 76:275-286.

Pisulewski, P. M., A. U. Okorie, P. J. Buttery, W. Haresign, and D. Lewis. 1981. Ammonia concentration and protein synthesis in the rumen. J. Sci. Food Agric. 32:759-766.

Pollott, G. E. 2004. Deconstructing milk yield and composition during lactation using biologically based lactation models. J. Dairy Sci. 87:2375-2387.

Raeth-Knight, M. L., J. G. Linn, and H. G. Jung. 2007. Effect of direct-fed microbials on performance, diet digestibility, and rumen characteristics of Holstein dairy cows. J. Dairy Sci. 90:1802-1809.

Rajala-Schultz, P. J., and W. J. A. Saville. 2003. Sources of variation in milk urea nitrogen in Ohio dairy herds. J. Dairy Sci. 86:16531661.

Rodriguez, F. 2003. Control of lactate accumulation in ruminants using Prevotella bryantii. PhD Thesis. Iowa State University, Ames.

Satter, L. D., and R. E. Roffler. 1974. Nitrogen requirement and utilization in dairy cattle. J. Dairy Sci. 58:1219-1237.

Sawanon, S., and Y. Kobayashi. 2006. Synergistic fibrolysis in the rumen by cellulolytic Ruminococcus flavefaciens and noncellullolytic Selenomonas ruminantium: Evidence in defined cultures. Anim. Sci. J. 77:208-214.

Stewart, C. S. 1977. Factors affecting the cellulolytic activity of rumen contents. Appl. Environ. Microbiol. 33:497-502.

Stewart, C. S., H. J. Flint, and M. P. Bryant. 1997. The rumen bacteria. Pages 10-72 in The Rumen Microbial Ecosystem. P. N Hobson and C. S. Stewart, ed. Thomson Science, London, UK.

Taylor, K. A. C. C. 1996. A simple colorimetric assay for muramic acid, lactic acid, glyceraldehyde, acetaldehyde and formaldehyde. Appl. Biochem. Biotechnol. 56:49-58.

Wattiaux, M. A., and K. L. Karg. 2004. Protein level for alfalfa and corn silage-based diets: 1. Lactational response and milk urea nitrogen. J. Dairy Sci. 87:3480-3491.

Weatherburn, M. W. 1967. Phenol-hypochlorite reaction for determination of ammonia. Anal. Chem. 39:971-974. 